УДК 616.34-008.64-089-07

DOI: $10.24061 / 1727-0847.17 .2 .2018 .7$

\title{
O.B. Pomap
}

Кафедра загальної хірургї (зав. - проф. В.П. Польовий) ВДНЗ України “Буковинський державний медичний університет”, м. Чернівці

\section{МОРФОЛОГІЧНІ ТА ФУНКЦІОНАЛЬНІ ЗМІНИ СЛИЗОВОЇ ОБОЛОНКИ КИШОК ЗА УМОВИ ГОСТРОГО НЕКРОТИЧНОГО ПАНКРЕАТИТУ}

\begin{abstract}
Резюме. Мета дослідження: дослідити морфологічні та функціональні зміни слизової оболонки кишок при гострому некротичному панкреатиті та їх вплив на транслокацію бактерій та ендотоксину. Матеріал і методи. У клініці в 74 пацієнтів та в експерименті на 60 білих щурах досліджували стан кишкового бар'єра при гострому некротичному панкреатиті. Досліджували морфологічні та гістологічні зміни слизової оболонки кишечнику, ферментативну активність у ній, стан мікрофлори та проникливість для ендотоксину. Результати дослідження та їх обговорення. У ранню фазу гострого некротичного панкреатиту бар'єрна функція кишечнику порушується за рахунок підвищення активності лізосомальних ферментів ( $\beta$-галактозідази вдвічі та $\mathrm{N}$-ацетил- $\beta$-глюкозамінідази втричі, $\mathrm{p}<0,05)$, що змінює якісний та кількісний склад глікопротеїнів приепітеліального шару слизової оболонки. Порушення кишкового бар'єра супроводжувалися бактеріальною транслокацією у внутрішні органи в $57,4 \%$ пацієнтів, які оперовані у ранні терміни (до 4 тижнів) захворювання, і в 90\% тварин після 72год експерименту. Високі концентрації ендотоксину (більше 0,30ЕО/мл), які надходять із кишечнику, активують специфічний прозапальний каскад через мембранний рецептор моноцитів/макрофагів CD14, що супроводжується розвитком синдрому системної запальної відповіді і мультиорганною недостатністю. Висновки: при гострому некротичному панкреатиті порушується структура і захисна функція приепітеліального слизового шару, відбувається колонізація слизової оболонки кишечнику патогенною та умовно патогенною грамнегативною мікрофлорою, що створює умови для міграції бактерій і транспорту ендотоксину в системну циркуляцію крові.
\end{abstract}

Ключові слова: гострий некротичний панкреатит; кишковий бар'єр; бактеріальна транслокація.

Гострий некротичний панкреатит (ГНП) - хірургічне захворювання, в основі якого лежить первинний асептичний некроз тканин підшлункової залози, що супроводжується розвитком синдрому системної запальної відповіді (ССЗВ) як при асептичному, так й інфікованому некрозі. За останні роки значно збільшилася кількість хворих з інфікованими формами ГНП і розвитком гнійно-септичних ускладнень, летальність при яких досягає $17-70 \%$ [1]. Визнання впливу вторинної інфекції на закономірність перебігу ГНП зумовлює необхідність вивчення патофізіології цього ускладнення, подальшої розробки методів діагностики, профілактики і лікування [2].

Мета дослідження: дослідити морфологічні та функціональні зміни слизової оболонки кишок за умови ГНП та їх вплив на транслокацію бактерій та ендотоксину (ЕТ).

Матеріал і методи. Обстежено 74 хворих, які оперовані з приводу ускладнень ГНП. Серед обстежених жінок було 22, чоловіків - 52, віком

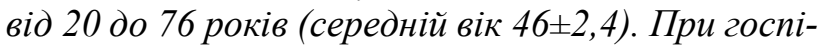
талізації пацієнтів оцінювали тяжскість ГНП за критеріями Атланта (2012), тяжкість стану пацієнтів - за шкалою АРАCHE II (Acute Physiology and Chronic Health Evaluation II). Пoрушення функиії кишок (ПФК) визначали згідно з рекомендачями робочої групи з абдомінальної патології (WGAP) Свропейського товариства медичної інтенсивної терапї̈ (ESICM) [3]. У ранні терміни захворювання оперовані 28, у більш пізні терміни (після 4-х тижнів) - 46 пацієнтів. При надходженні хворих у 42 осіб під час проведення гастродуоденофіброскопії забирали вміст проксимального відділу тонкої кишки (ТK), а під час операиії - випіт із черевної порожнини, вміст рідинних скупчень чепчевої сумки, некротичних тканин підшлунко-вої залози, кіст і абсиесів, на- 
далі проводили бак-теріологічне дослідження. Визначення кількісного вмісту ЕТ у сироватиі крові проводили за ЛАЛ-тестом (Toxin Sensor Chromatogenic LAL Endotoxin Assay Kit L00350,

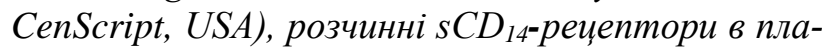
змі крові визначали імуноферментним методом. Моделювали ГНП на 60 білих шурах-самиях масою 200-220г за методом [4] у модифікачії. По 7 щурів кожної групи виводили з експерименту передозуванням натрію тіопентала через 6, 12, 24, 48, 72год. Дослідним матеріалом були тканини підилункової залози, мезентеріальних лімфатичних вузлів, портальна венозна кров, а також слизовий гель дистального відділу тонкої, які використовували для дослідження мікрофлори. Морфологічні і біохімічні зміни приепітеліального шару i слизової оболонки оцінювали за індексом ушкодження слизової [4] i показниками вуглеводних компонентів, що входять до складу глікопротеїнів муцину [5]. Усі отримані ицифрові дані опраиьовані статистично з використанням критерію (t) Стьюдента та критерію Вілкоксона. Різницю між порівнювальними величинами вважали вірогідною при $p<0,05$.

Результати дослідження та їх обговорення. Після індукції ГНП відзначали порушення якісного та кількісного складу вуглеводно-білкових компонентів приепітеліального шару слизу кишечнику, передусім глікопротеїнів, як результат гідролізу активованими лізосомальними ферментами. Через 6 год експерименту концентрація вільної, не зв'язаною з білком, галактози вірогідно $(\mathrm{p}<0,05)$ підвищилася на 48\%, через 12 год - на $76 \%$, сіалових кислот, відповідно, на $37,6 \%$ і 40\% $(\mathrm{p}<0,05)$, фукози - у два і три рази $(\mathrm{p}<0,02)$. СК i ФК займають кінцеве положення в олігосахаридному ланцюгу, визначають його заряд, значення $\mathrm{pH}$, ступінь в'язкості і потенційні ділянки для зв'язку з індігенною мікрофлорою, які забезпечують колонізаційну резистентність кишкового бар'єра [6]. Водночас відзначали значно потовщену стінку ТК, здебільшого слизовий шар, який легко відшаровувався у порожнину кишки. На деяких ділянках ТК спостерігали втрату цілісності слизової оболонки за типом виразкового дефекту. Індекс ушкодження слизової оболонки на 48 год експерименту становив $3,3 \pm 0,14$.

Порушення структури муцинів і морфологічні зміни слизової оболонки супроводжувалися елімінацією індигенної анаеробної мікрофлори (табл. 1). Через 24 годин від початку експерименту популяційний рівень біфідобактерій зменшився на 7,8\%, лактобактерій - на $8,7 \%$ і еубактерій - на $14,6 \%(p<0,05)$. Через 48 годин і до закін- чення експерименту із слизової болонки ободової і тонкої кишки практично не виділяли еубактерії. Слизову оболонку активно колонізували невластиві даному біотопу клостридії, стафілококи, а також патогенні та умовно патогенні ентеробактерії на високому ПР (3,07-5,39 $\lg$ КУО/г), що дозволяло цій мікрофлорі подолати кишковий бар'єр i здійснювати міграцію (транслокацію) у внутрішнє середовище організму. Через 24 годин після індукції ГНП E.colii i P. mirabilis проникали у мезентеріальні лімфовузли, через 48 годин E.coli i S.epidermidis виділяли 3 портальної крові, тканини підшлункової залози, очеревинної порожнини. У більш пізні терміни (>72 годин) спектр мікрофлори, що виділяли із тканин і крові в 90\% експериментальних тварин, розширюється за рахунок E.coli $\mathrm{HLY}^{+}$, S.aureus, K. pneumonia, E.Tarda.

До операції з проксимального відділу ТК у 29 $(69 \%)$ iз 42 обстежених хворих на ГНП виділили та ідентифікували 8 штамів грамнегативних патогенних та умовно-патогенних бактерій, зокрема E.coli (65\%), K.pneumoniae (17,3\%), P. aeruginosa $(13,7 \%)$, E. faecalis $(13,7 \%)$ і один штам грампозитивних бактерій (S. aureus, 20,6\%), хоч у здорових людей проксимальний відділ ТК може бути стерильним, деколи нечасто виявляють стрептококи, стафілококи, молочно-кислі палички і гриби у невеликій кількості $\left(10^{3}-10^{4}\right.$ в мл). У $16(57,4 \%)$ iз 28 пацієнтів, які оперовані в ранні терміни захворювання (до 4-х тижнів), де виключена можливість інфікування із зовнішнього середовища, iз деструктивних тканин підшлункової залози у 9 пацієнтів, вмісту чепцевої сумки - у 4 і черевної порожнини - 3 хворих, висівали типові представники ентеробактерій: їх морфологічні, тинкторіальні і культуральні властивості були практично ідентичні мікрофлорі ТК, що виділена у пацієнтів до операції. Так же, як і до операції, частіше висівалися E.coli (87,5\%), K.pneumoniae $(62,5 \%)$, P. aeruginosa $(62,5 \%)$, E. faecalis $(31,2 \%)$ i S. aureus, $(37,5 \%)$, що засвідчує про транслокацію бактерій за рахунок порушення бар'єрної функції кишечнику.

За результатами проведеного дослідження, концентрація ЕТ грамнегативних бактерій у плазмі крові здорових людей становила в середньому $0,11 \pm 0,05 \mathrm{EO} /$ мл (діапазон коливання від 0 до $0,13 \mathrm{EO} /$ мл). У хворих на ГНП концентрація ЕТ була вірогідно вищою $(\mathrm{p}<0,05)$, ніж у здорових осіб, що залежить від ступеня кишкової недостатності (КН) і тяжкості ГНП. При ПФК І ступеня (ризик дисфункції кишечнику) у 38 (51\%) хворих відзначили тимчасовий парез кишечнику, рефлюкс або блювоту, що швидко самостійно ми- 
нали, а підвищення концентрації ЕT удвічі не впливали на загальний стан хворих. ПФК II ступеня (кишкова дисфункція) у $16(21,6 \%)$ характеризувалася гострим розвитком парезу кишок, великим (>500мл) залишковим об' ємом шлунка, рефлюксом, внутрішньочеревною гіпертензією; концентрація ЕТ у плазмі крові у чотири рази $(\mathrm{p}<0,01)$ перевищувала показники здорових осіб. У хворих клінічно і лабораторно виявляли порушення дихання, кровообігу i функції нирок. У крові ЕТ взаємодіє з ЕТ-зв’язуючим білком і реалізує свої ефекти через мембранні CD14-рецептори моноцитів/макрофагів (mCD14) [7]. Проведення активаційного сигналу через TOLL-подібний корецептор служить поштовхом для початку експресії моноцитами/макрофагами генів цитокінів, NO-синтазиі генів інших медіаторів, ферментів і регуляторних молекул запалення, надлишкове утворення яких викликає розвиток ССЗВ i органної недостатності. Після трансляції сигналу mCD14-рецептор відділяється від макрофага і перетворюється в розчинну форму sCD14-рецептор.
Рівень sCD14-рецепторів у плазмі крові майже у сім разів $(\mathrm{p}<0,01)$ перевищував референтний рівень осіб КГ (табл. 2). Органна недостатність у хворих із ПФК II ступеня корегувалася протягом наступних 2 діб, тобто була транзиторною. ПФК III i особливо IV ступеня (критична кишкова недостатність) супроводжувалися ендотоксинемією 3 тяжким впливом на віддалені органи. Концентрація ЛПС у плазмі крові пацієнтів 3 тяжким ГНП підвищилася, відповідно, до $0,49 \pm 0,07 \mathrm{EO} /$ мл і $0,88 \pm 0,11 \mathrm{EO} /$ мл, а концентрація $\mathrm{sCD} 14$ - до

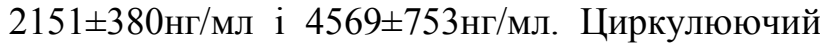
sCD14-рецептор викликає індукцію запалення в клітинах, що не мають мембранних CD14-рецепторів і не реагують на ЛПС [7], у першу чергу ендотелію судин, епітелію слизових, у тому числі кишечнику, що супроводжується екстравазацією рідини, гіповолемією і артеріальною гіпотонією та розвитком мультиорганної недостатності. Тяжкість стану пацієнтів перевищувала 20 балів за шкалою APACHE II, у хворих із ПФК IV ступеня - понад 30 балів.

Табличя 1

Активність лізосомальних ферментів, протеолітична і колагенолітична активність у слизовій оболонці тонкої кишки при гострому експериментальному панкреатиті $\mathrm{M} \pm \mathbf{m}$

\begin{tabular}{|c|c|c|c|c|c|}
\hline $\begin{array}{c}\text { Етапи } \\
\text { дослідження }\end{array}$ & $\begin{array}{c}\beta \text {-галактозі- } \\
\text { даза, МО }\end{array}$ & $\begin{array}{c}\text { N-ацетил- } \beta- \\
\text { глюкозамі- } \\
\text { нідаза, МО }\end{array}$ & $\begin{array}{c}\text { Лізис азо- } \\
\text { казеїну } \\
\text { Е440/мл/год }\end{array}$ & $\begin{array}{c}\text { Лізис азо- } \\
\text { колу, } \\
\text { Е440/мл/год }\end{array}$ & $\begin{array}{c}\text { Індекс ушкод- } \\
\text { ження слизової } \\
\text { оболонки, у.о. }\end{array}$ \\
\hline Контроль & $3,48 \pm 0,008$ & $1,16 \pm 0,006$ & $0,523 \pm 0,029$ & $0,1365 \pm 0,012$ & 0 \\
\hline через 6 год & $7,96 \pm 0,015^{*}$ & $4,30 \pm 0,01^{*}$ & $0,693 \pm 0,09$ & $0,1605 \pm 0,022$ & $2,1 \pm 0,12^{*}$ \\
\hline через 12 год & $6,66 \pm 0,014^{*}$ & $3,75 \pm 0,011^{*}$ & $0,639 \pm 0,03$ & $0,1637 \pm 0,009$ & $2,8 \pm 0,14^{*}$ \\
\hline через 24 год & $5,18 \pm 0,013^{*}$ & $3,14 \pm 0,013^{*}$ & $0,678 \pm 0,007$ & $0,1560 \pm 0,019$ & $3,1 \pm 0,11^{*}$ \\
\hline через 48 год & $5,73 \pm 0,011^{*}$ & $2,33 \pm 0,012^{*}$ & $0,688 \pm 0,011$ & $0,1665 \pm 0,022$ & $3,2 \pm 0,16^{*}$ \\
\hline через 72 год & $4,37 \pm 0,03$ & $2,12 \pm 0,012$ & $0,668 \pm 0,009$ & $0,1766 \pm 0,019$ & $2,9 \pm 0,12^{*}$ \\
\hline через 96 год & $3,54 \pm 0,021$ & $2,27 \pm 0,012$ & $0,773^{*} \pm 0,01$ & $0,1688 \pm 0,015$ & $3,1 \pm 0,16^{*}$ \\
\hline
\end{tabular}

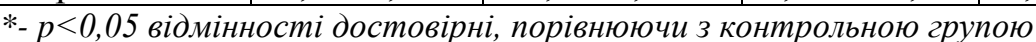

Таблицяя 2

Видовий склад та популяційний рівень мікрофлори слизової оболонки дистального відділу тонкої кишки експериментальних тварин з гострим деструктивним панкреатитом $(\mathrm{M} \pm \mathrm{m})$

\begin{tabular}{|c|c|c|c|c|c|c|c|c|}
\hline \multirow{3}{*}{$\begin{array}{l}\text { Виділені } \\
\text { мікро-організми }\end{array}$} & \multicolumn{8}{|c|}{ Термін спостереження, години } \\
\hline & \multicolumn{2}{|c|}{$\begin{array}{c}\text { Контрольна } \\
\text { група }\end{array}$} & \multicolumn{2}{|c|}{24} & \multicolumn{2}{|r|}{48} & \multicolumn{2}{|r|}{72} \\
\hline & $\mathrm{N}$ & $\lg \mathrm{KУO} / \Gamma$ & $\mathrm{N}$ & $\operatorname{lg~KУO/\Gamma ~}$ & $\mathrm{N}$ & $\operatorname{lg~КУO/Г~}$ & $\mathrm{N}$ & $\lg \mathrm{KУO/Г}$ \\
\hline Біфідобактерії & 10 & $6,51 \pm 0,11$ & 5 & $6,37 \pm 0,15$ & 4 & $5,39 \pm 0,11$ & 3 & $5,01 \pm 0,09 *$ \\
\hline Лактобактерії & 10 & $6,77 \pm 0,33$ & 6 & $6,17 \pm 0,38$ & 5 & $5,11 \pm 0,09$ & 4 & $4,34 \pm 0,11^{*}$ \\
\hline Бактероїди & 10 & $5,27 \pm 0,37$ & 6 & $5,78 \pm 0,05$ & 6 & $5,75 \pm 0,15$ & 6 & $5,89 \pm 0,07$ \\
\hline Клостридії & - & - & - & - & 2 & $2,95 \pm 0,10^{*}$ & 4 & $3,68 \pm 0,17^{*}$ \\
\hline Ешерихії & 6 & $4,11 \pm 0,17$ & 6 & $4,54 \pm 0,11$ & 5 & $4,71 \pm 0,12$ & 5 & $4,82 \pm 0,08$ \\
\hline Едварсієли & - & - & - & - & 2 & $2,46 \pm 0,09 *$ & 2 & $3,79 \pm 0,12 *$ \\
\hline Клебсієли & - & - & - & - & 2 & $2,39 \pm 0,12^{*}$ & 3 & $3,86 \pm 0,15^{*}$ \\
\hline Протеї & - & - & - & - & 1 & $2,19 \pm 0.13^{*}$ & 5 & $4,01 \pm 0.15^{*}$ \\
\hline Ентерококи & 5 & $6,31 \pm 0,21$ & 5 & $5,47 \pm 0.14$ & 4 & $5,11 \pm 0.13^{*}$ & 3 & $4,01 \pm 0.15^{*}$ \\
\hline Стафілококи & - & - & - & - & 1 & 2,41 & 3 & $3,83 \pm 0,12^{*}$ \\
\hline
\end{tabular}

*- $<<0,05$ відмінності достовірні, порівнюючи з контрольною групою 
Висновки. 1. При гострому некротичному панкреатиті порушується структура і захисна функція приепітеліального слизового шару, відбувається колонізація слизової оболонки кишечнику патогенною та умовно патогенною грамнегативною мікрофлорою, створюються умови для міграції бактерій і транспорту ендотоксину в системну циркуляцію крові. 2. Порушення кишкового бар'єра спричиняє транслокацію патогенних бактерій у внутрішні органи в 57,4\% хворих на ГНП у ранні терміни (до 4-х тижнів) захворювання, і в
90\% тварин після 72 год експерименту. Висока концентрація ендотоксину (більше 0,30ЕО/мл), що надходить із кишечнику, активує специфічний прозапальний каскад через мембранний рецептор моноцитів/макрофагів CD14 і зумовлює розвиток синдрому системної запальної відповіді.

Перспективи подальших досліджень. Подальші дослідження порушень кишкового бар'єра при гострому некротичному панкреатиті доцільно проводити щодо проникливості слизової оболонки різних відділів шлунково-кишкового тракту.

\section{Список використаної літератури}

1. Peery AF, Dellon ES, Lund J, Crockett SD, McGowan CE, Bulsiewicz WJ, et al. Burden of gastrointestinal disease in the United States: 2012 update. Gastroenterology. 2012 Nov; 143(5):1179-87. doi: 10.1053/j.gastro.2012.08.002.

2. Phillip V., Steiner JM, Algül H. Early phase of acute pancreatitis: assessment and management. World $J$ Gastrointest Pathophys. 2014 May; 5(3):158-64. doi: 10.4291/wjg.v5.i3.158.

3. Reintam Blaser A, Malbrain ML, Starkopf J, FruhwaldS, Jakob SM, De Waele J, et al. Gastrointestinal function in intensive care patients: terminology, definitions and management. Recommendations of the ESICM Working Group on Abdominal Problems. Intensive Care Med. 2012 Mar; 38(3):384-94.

4. Liang HY, Chen T, Wang T, Huang Z, Yan HT, Tang LJ. Time course of intestinal barrier function injury in a sodium taurocholate-induced severe acute pancreatitis in rat model. J Dig Dis. 2014 Jul; 15(7):386-93. doi: 10.1111/1751-2980.12148.

5. Rotar $O$, Rotar $V$. Effect of L-lysine aescinate on structure and permeability of intestinal barrier during acute pancreatitis. Pancreatology. 2012 Jun; 12(6):508. doi: 10.1016/j.pan.2012.11.021

6. Hu B, Sun R, Wu A, Ni Y, Liu J, Guo F, Ying L, Ge G et al. Severity of acute gastrointestinal injury grade is a predictor of all-cause mortality in critically ill patients: a multicenter, prospective, observational study. Crit 7. Care. 2014 Jul; 21(1):188. doi: 10.1186/s13054-017-1780-4.

Shozushima T, Takahashi G, Matsumoto N, Kojika M, Okamura Y, Endo S. Usefulness of presepsin (sCD14 ST) measurements as a marker for the diagnosis and severity of sepsis that satisfed diagnostic criteria of systemic infammatory response syndrome. J Infect Chemother. 2011 Dec; 17(6):764-9. doi: 10.1007/s10156011-0254-x.

\section{References}

1. Peery AF, Dellon ES, Lund J, Crockett SD, McGowan CE, Bulsiewicz WJ1, et al. Burden of gastrointestinal disease in the United States: 2012 update. Gastroenterology. 2012 Nov;143(5):1179-1187.e3. doi: 10.1053/j.gastro.2012.08.002.

2. Phillip V, Steiner JM, Algül H. Early phase of acute pancreatitis: assessment and management. World $J$ Gastrointest Pathophys. 2014 Aug; 5(3):158-64. doi: 10.4291/wjg.v5.i3.158.

3. Reintam Blaser A, Malbrain ML, Starkopf J, Fruhwald S, Jakob SM, De Waele J, et al. Gastrointestinal function in intensive care patients: terminology, definitions and management. Recommendations of the ESICM Working Group on Abdominal Problems. Intensive Care Med. 2012 Mar;38(3):384-94. doi: 10.1007/s00134011-2459-y. Epub 2012 Feb 7.

4. Liang HY, Chen T, Wang T, Huang Z, Yan HT, Tang LJ. Time course of intestinal barrier function injury in a sodium taurocholate-induced severe acute pancreatitis in rat model. J Dig Dis. $2014 \mathrm{Jul;}$ 15(7):386-93. doi: 10.1111/1751-2980.12148.

5. Rotar $O$, Rotar $V$. Effect of L-lysine aescinate on structure and permeability of intestinal barrier during acute pancreatitis. Pancreatology. 2012 Jun; 12(6):508. doi: 10.1016/j.pan.2012.11.021

6. Hu B, Sun R, Wu A, Ni Y, Liu J, Guo F, et al. Severity of acute gastrointestinal injury grade is a predictor of all-cause mortality in critically ill patients: a multicenter, prospective, observational study. Crit Care. 2017 Jul 14;21(1):188. doi: 10.1186/s13054-017-1780-4.

7. Shozushima T, Takahashi G, Matsumoto N, Kojika M, Okamura Y, Endo S. Usefulness of presepsin (sCD14-ST) measurements as a marker for the diagnosis and severity of sepsis that satisfied diagnostic criteria of systemic inflammatory response syndrome. J Infect Chemother. 2011 Dec;17(6):764-9. doi: 10.1007/s10156-011-0254-x. 


\section{МОРФОЛОГИЧЕСКИЕ И ФУНКЦИОНАЛЬНЫЕ ИЗМЕНЕНИЯ СЛИЗИСТОЙ ОБОЛОЧКИ КИШЕЧНИКА ПРИ ОСТРОМ НЕКРОТИЧЕСКОМ ПАНКРЕАТИТЕ}

Резюме. Цель работы - исследовать морфологические и функциональные изменения слизистой оболочки кишечника при остром некротическом панкреатите и их влияние на транслокацию бактерий и эндотоксина. Материал и методы. В клинике у 74 пациентов и в эксперименте на 60 белых крысах исследовали состояние кишечного барьера при остром некротическом панкреатите. Изучали морфологические и гистологические изменения в слизистой оболочки кишечника, ферментативную активность в ней, состояние микрофлоры и проницательность для эндотоксина. Результаты и обсуждение. В раннюю фазу острого некротического панкреатита барьерная функция кишечника нарушается за счет повышения активности лизосомальных ферментов ( $\beta$-галактозидазы вдвое и $\mathrm{N}$-ацетил- $\beta$ глюкозаминидазы втрое, $\mathrm{p}<0,05)$, что изменяет качественный и количественный состав гликопротеинов приэпителиального слоя слизистой оболочки. Нарушение кишечного барьера сопровождались бактериальной транслокацией во внутренние органы в 57,4\% пациентов, прооперированных в ранние сроки (до 4 недель) заболевания, и в 90\% животных после 72ч эксперимента. Высокие концентрации эндотоксина (более $0,30 Э Е /$ л), которые поступают из кишечника, активируют специфический провоспалительных каскад через мембранный рецептор моноцитов/макрофагов CD14, что сопровождается развитием синдрома системного воспалительного ответа и мультиорганной недостаточностью. Выводы. При остром некротическом панкреатите нарушается структура и защитная функция приэпителиального слоя слизи, происходит колонизация слизистой оболочки кишечника патогенной и условно патогенной грамотрицательной микрофлорой, что создает условия для миграции бактерий и транспорта эндотоксина в системную циркуляцию крови.

Ключевые слова: острый некротический панкреатит; кишечный барьер; бактериальная транслокация.

\section{MORPHOLOGICAL AND FUNCTIONAL CHANGES OF INTESTINAL MUCOSA WITH ACUTE NECROTIZING PANCREATITIS}

Abstract. The purpose is to investigate morphological and functional changes of the intestinal mucosa during acute necrotic pancreatitis and their effect on the translocation of bacteria and endotoxin. Material and methods. The conditions of the intestinal barrier were studied on 74 patients in the clinic and 60 white rats in the experiment during acute necrotic pancreatitis. Morphological and histological changes of the mucosal layer of the intestine, its enzyme activity, the microflora and its permeability for the endotoxin were studied. Results and discussion. During the early phase of acute necrotic pancreatitis barrier function of the intestine is disturbed at the expense of increasing the activity of lysosomal enzymes ( $\beta$-galactosidase double and $\mathrm{N}$-acetyl- $\beta$-glucosaminidase triple as much, $\mathrm{p}<0.05$ ), which caused the qualitative and quantitative changes of composition of glycoproteins in the epithelial layer of the mucous membranes. Disorders of the intestinal barrier were accompanied by bacterial translocation to the internal organs in $57.4 \%$ of patients who were operated during the early stages (up to 4 weeks) of the disease and in $90 \%$ of the animals after 72 hours of the experiment. High concentrations of endotoxin (over than $0.30 \mathrm{EO} / \mathrm{ml}$ ) released from the intestine activates a specific pro-inflammatory cascade through the membrane receptor of monocytes/macrophages CD14, which is associated with the development of a systemic inflammatory response syndrome and multiple organ failure. Conclusions. During acute necrotizing pancreatitis the structure and protective function of the pre-epithelial mucosal layer are disordered, colonization of intestine by pathogenic and conditionally pathogenic gram-negative microflora occurs, promoting migration of bacteria and transport of endotoxin into the systemic blood circulation.

Key words: acute necrotizing pancreatitis, intestinal barrier, bacterial translocation.

Відомості про авторів:

Ротар Олександр Васильович - кандидат медичних наук, доцент кафедри загальної хірургії ВДНЗ України “Буковинський державний медичний університет”;

Information about authors:

Rotar Oleksandr Vasylovych - PhD, Associated professor of General Surgery of HSEE of Ukraine "Bukovinian State Medical University" 